\title{
The Assessment of Business Performance Based on a Balanced Scorecard
}

\author{
Maria S. Rybyantseva ${ }^{1, *}$ Yuliya N. Galitskaya ${ }^{1, a}$ \\ ${ }^{1}$ Kuban State Technological University, Krasnodar, Russia \\ a'Email: y_n_g@mail.ru \\ *Corresponding author. Email: Riban1@ mail.ru
}

\begin{abstract}
Energy companies establish business models with the account of their financial goals and key performance indicators. In order to develop a Balanced Scorecard (a balanced system of indicators) for energy companies, it is advisable to apply key performance indicators in four perspectives: financial, customer, internal business process, and learning and growth. Using the method of expert survey, the authors of the present article have ranked the indicators within each strategic perspective. The ranking data received can lay the foundation for the development of incentive systems. Additionally, the article illustrates the example case of developing key performance indicators; it can be used to systematize approaches to the development of key performance indicators for branches of energy companies.
\end{abstract}

Keywords: Balanced Scorecard, key performance indicators, business processes, energy companies

\section{INTRODUCTION}

The goals and indicators of a Balanced Scorecard (a balanced system of indicators) depend on a company's worldview and strategy, and focus on its activity in four perspectives: financial, customer, internal business processes, and learning and growth. A Balanced Scorecard is integrated into company structure and applied to all its levels, from the management to individual employees.

A significant number of Russian energy companies establish their business models according to company financial goals and key performance indicators. Meanwhile, having introduced a Balanced Scorecard into their business models, they are more likely to fulfil the true potential of key performance indicators and to analyse internal processes, market development and personnel development.

Theoretical justification of the methods for assessing business performance based on the Balanced Scorecard system allows making recommendations concerning the implementation of this system in different industries, taking sector particularities into account.

\section{THEORETICAL AND METHODOLOGICAL FRAMEWORK FOR THE ASSESSMENT OF BUSINESS PERFORMANCE BASED ON THE BALANCED SCORECARD}

In their work "Balanced Scorecard. Translating strategy into action", Robert Kaplan and David Norton assert that "the collision between the irresistible force to build long-range competitive capabilities and the immovable object of the historical-cost financial accounting model has created a new synthesis: the Balanced Scorecard. The Balanced Scorecard complements financial measures of past performance with measures of the drivers of future performance. The objectives and measures of the scorecard are derived from an organization's vision and strategy. The objectives and measures view organizational performance from four perspectives: financial, customer, internal business process, and learning and growth." [1]

The Balanced Scorecard and Strategy Maps are integrated into organization, thus setting the framework of indicators and strategy maps at the departmental level.

The principle underlying the Balanced Scorecard is the principle of consistency, while the main objective of its implementation is the development of KPIs (including calculation, assessment and revision methodology). For energy companies, it is critical to have a list of measured KPIs that reflect the core aspects of company activity. The overall performance of a power grid company depends on the efficiency of:

- each business area;

- each structural unit within a business areas;

- each employee in a structural unit

The stages of the development of a Balanced Scorecard are presented in "Table I". [2] 
TABLE I. THE STAGES OF THE DEVELOPMENT OF A BALANCED SCORECARD

\begin{tabular}{|c|c|}
\hline Stage & Description \\
\hline Clarifying strategies & $\begin{array}{l}\text { Prerequisites for strategy development; } \\
\text { Selecting strategic orientation; } \\
\text { Integrating the Balanced Scorecard into strategy development. }\end{array}$ \\
\hline $\begin{array}{l}\text { Organizational } \\
\text { arrangements }\end{array}$ & $\begin{array}{l}\text { Appointing a structural unit responsible for the development of the Balanced } \\
\text { Scorecard; } \\
\text { Sequencing works on creating the Balanced Scorecard; } \\
\text { Identifying information channels and communication types; dividing responsibility; } \\
\text { Standardizing work methods and content; } \\
\text { Considering major indicators. }\end{array}$ \\
\hline $\begin{array}{l}\text { Development of the } \\
\text { Balanced Scorecard }\end{array}$ & $\begin{array}{l}\text { Identifying strategic goals and the architecture of the Balanced Scorecard; } \\
\text { Clarifying cause-effect relationships; } \\
\text { Selecting measuring units; } \\
\text { Setting target values; } \\
\text { Identifying strategic actions and designing a strategy map. }\end{array}$ \\
\hline $\begin{array}{c}\text { Implementation of the } \\
\text { Balanced Scorecard }\end{array}$ & $\begin{array}{l}\text { Applying the Balanced Scorecard to individual structural units; } \\
\text { Coordinating the Balanced Scorecard between individual structural units; } \\
\text { Quality assurance and process documentation. }\end{array}$ \\
\hline
\end{tabular}

The necessary instruments contributing to successful development and implementation of a Balanced Scorecard include the following:

- implementation of a quality management system (a part of the general management system of a company aimed at ensuring sustained business processes and products);

- description of business processes that provide thorough understanding of the processes taking place in the organization;

- application of benchmarking;

- risk management;

- selection (development) and implementation of the internal information system to ensure prompt documentation and information transfer. [3]
Shifting the management focus from the interests of the owner to the customers' interests with their heterogeneous goals and objectives, poses a challenge to the development of a universal system of indicators.

Key indicators should be understood as financial or non-financial measures that most accurately describe any phenomenon or process and conform to the principles of materiality, transparency and verifiability. These principles are of the utmost significance in terms of taking well-informed managerial decisions and promoting the interests of all stakeholder groups.

"Table II" indicated different characteristics of key performance indicators.

TABLE II. KEY PERFORMANCE INDICATORS

\begin{tabular}{|c|l|}
\hline $\begin{array}{c}\text { Characteristics } \\
\text { The objectives of KPI } \\
\text { application }\end{array}$ & $\begin{array}{l}\text { Systematization and structuring of the planning process. } \\
\text { Defining the expectations of all stakeholder groups in quantitative and qualitative terms within the } \\
\text { selected development strategy. } \\
\text { Promoting the transparency of the company's activities in order to increase management } \\
\text { efficiency. }\end{array}$ \\
\hline Requirements to KPIs & $\begin{array}{l}\text { Consistent with the goals and objectives of the organization. } \\
\text { Assess the activity of the organization as a socio-economic system. } \\
\text { Comply with the principle of materiality. } \\
\text { Adequately reflect the organization's activity within its stakeholders' interests. } \\
\text { Characterized by the high level of relevance and verifiability. }\end{array}$ \\
& $\begin{array}{l}\text { Largely focus on international standards, recommendations and best practices. } \\
\text { Provide quantitative measurability and comparability of the assessment. } \\
\text { Balanced in their types and planning timeframes. } \\
\text { Simple and transparent; can be influenced by company employees. }\end{array}$ \\
\hline $\begin{array}{c}\text { KPIs principles of } \\
\text { Ene UES } \text { (Unified } \\
\text { Russia) }\end{array}$ & $\begin{array}{l}\text { Limited number of KPIs; comparability; balance; pre-approval; individual character; mandatory } \\
\text { performance; equality; motivation; joint responsibility; accuracy; and system approach. }\end{array}$ \\
\hline $\begin{array}{c}\text { Management } \\
\text { functions }\end{array}$ & $\begin{array}{l}\text { Goal setting; standardization and control; coordination; delineation of authority and } \\
\text { responsibilities between different management levels. }\end{array}$ \\
\hline
\end{tabular}


The economic literature offers numerous approaches to classification of key performance indicators. Classification criteria and the types of KPIs are to be found in "Table III".

TABLE III. CLASSIFICATION OF KEY PERFORMANCE INDICATORS

\begin{tabular}{|c|c|}
\hline Classification criteria & $\begin{array}{l}\text { Types of key performance indicators } \\
\end{array}$ \\
\hline Assessment focus & $\begin{array}{l}\text { Key national indicators } \\
\text { Key performance indicators }\end{array}$ \\
\hline Operating activity & $\begin{array}{l}\text { Operating activity indicators } \\
\text { Investment activity indicators } \\
\text { Financial activity indicators }\end{array}$ \\
\hline Source data & $\begin{array}{l}\text { Quantitative indicators } \\
\text { Qualitative indicators }\end{array}$ \\
\hline Methodological approaches & $\begin{array}{l}\text { Absolute indicators } \\
\text { Relative indicators }\end{array}$ \\
\hline Economic content & $\begin{array}{l}\text { Physical indicators } \\
\text { Cost indicators }\end{array}$ \\
\hline Generalization level & $\begin{array}{l}\text { Integral indicators } \\
\text { Individual indicators } \\
\text { KPI conditions }\end{array}$ \\
\hline Method of calculation & $\begin{array}{l}\text { Target indicators } \\
\text { Actual indicators }\end{array}$ \\
\hline Type & $\begin{array}{l}\text { Indicators with numerical target value } \\
\text { Indicative indicators }\end{array}$ \\
\hline Functional area & $\begin{array}{l}\text { Personnel management indicators } \\
\text { Procurement management indicators } \\
\text { Property management indicators } \\
\text { Accounting and reporting indicators } \\
\text { Legal support indicators } \\
\text { Public relations indicators } \\
\text { Cross-cutting indicators [4] }\end{array}$ \\
\hline Planning time-frame & $\begin{array}{l}\text { Operating indicators } \\
\text { Strategic indicators [5] }\end{array}$ \\
\hline Time factor & $\begin{array}{l}\text { Static indicators } \\
\text { Dynamic indicators }\end{array}$ \\
\hline Stakeholders' interests & $\begin{array}{l}\text { Technical indicators } \\
\text { Internal economic indicators } \\
\text { Financial indicators [6] }\end{array}$ \\
\hline
\end{tabular}

This classification can be taken into account when developing the KPI system for a particular organization.

\section{DESIGNING THE SYSTEM OF KPIS FOR} BUSINESS DEVELOPMENT

Traditionally, energy companies adapt a Balanced Scorecard to their companies' business models and change the company processes so that they focus on four strategic objectives: reducing costs, raising company profile, improving customer service, and increasing reliability and productivity.

The authors of the article have developed key performance indicators for the PJSC "KubanEnergo", the largest power grid company in Krasnodar Krai and the Republic of Adygea ("Table IV").

TABLE IV. RECOMMENDED KEY PERFORMANCE INDICATORS WITH A BREAKDOWN INTO STRATEGIC PERSPECTIVES

\begin{tabular}{|c|l|}
\hline Perspectives & \multicolumn{1}{|c|}{ Recommended KPIs } \\
\hline Financial & Accounts receivable collection period \\
Overdue receivables \\
Receivables and payables ratio \\
Equity to total assets \\
Return on sales \\
Return on investment \\
\\
Quick liquidity ratio \\
Cash flow synchronicity ratio \\
& Plowback ratio \\
& Fixed asset renewal ratio \\
\hline
\end{tabular}




\begin{tabular}{|c|c|}
\hline Perspectives & Recommended KPIs \\
\hline Customer & $\begin{array}{l}\text { Average share of customers with regular power outages } \\
\text { Share of high profile customer dissatisfaction } \\
\text { New customers } \\
\text { Complaints per } 1,000 \text { customers } \\
\text { Sales volume } \\
\text { Share of sales outside the traditional business area } \\
\text { Claims won and settled ratio } \\
\text { Payment for the energy supplied } \\
\text { Share of A-Customer turnover } \\
\text { Customer loyalty }\end{array}$ \\
\hline $\begin{array}{c}\text { Internal business } \\
\text { processes }\end{array}$ & $\begin{array}{l}\text { Average duration of power outages in the system } \\
\text { Total circuit losses } \\
\text { Power recovery standard time } \\
\text { Annual peak demand } \\
\text { Use of electrical station installed capacity } \\
\text { Average delay in reporting } \\
\text { Annual increased costs for improving electricity grid quality } \\
\text { Total active investments in the current quarter } \\
\text { Instances of illegal consumption detected } \\
\text { Equipment downtime }\end{array}$ \\
\hline $\begin{array}{l}\text { Personnel (Learning } \\
\text { and growth) }\end{array}$ & $\begin{array}{l}\text { Training costs } \\
\text { Average tuition fee } \\
\text { Personnel turnover } \\
\text { Number of suggested improvements } \\
\text { Share of managers with management degrees } \\
\text { Average length of employment in the company } \\
\text { Share of employees with higher education } \\
\text { Employee absenteeism } \\
\text { Personnel satisfaction index } \\
\text { Share of payroll in the revenue }\end{array}$ \\
\hline
\end{tabular}

In order to rank the indicators within each strategic perspective, the authors have applied the method of expert survey. When organizing expert assessment, the following aspects should be taken into consideration:

- selecting competent and well-qualified people as experts (Deputy Security Director, Assistant Director for technological connection, Deputy Chief Engineer for power line operation, HR Director, Chief Accountant, etc.;

- conducting a survey and obtaining the information of interest from experts;

- selecting the methods for processing expert information;
- assessing and interpreting the obtained results.

For the purpose of conducting analysis, the authors have used the ranking method, which requires each expert to sort the indicators in descending order of importance $(1,2, \ldots, n)$. If the expert cannot rank the importance of two or more factors differently, the same ranks are assigned.

Thus, ten experts have assessed ten KPIs on a scale of one to ten. The results of the examination are available in "Table V".

TABLE V. The RESUlts OF THE ASSESSMENT OF THE "FinANCIAL" STRATEGIC PERSPECTIVE

\begin{tabular}{|c|l|l|l|l|l|l|l|l|l|l|}
\hline Indicator & $\mathbf{E}_{\mathbf{1}}$ & $\mathbf{E}_{\mathbf{2}}$ & $\mathbf{E}_{\mathbf{3}}$ & $\mathbf{E}_{\mathbf{4}}$ & $\mathbf{E}_{\mathbf{5}}$ & $\mathbf{E}_{\mathbf{6}}$ & $\mathbf{E}_{\mathbf{7}}$ & $\mathbf{E}_{\mathbf{8}}$ & $\mathbf{E}_{\mathbf{9}}$ & $\mathbf{E}_{\mathbf{1 0}}$ \\
\hline Accounts receivable collection period & 9 & 10 & 9 & 8 & 5 & 8 & 10 & 8 & 10 & 8 \\
\hline Overdue receivables & 6 & 5 & 6 & 6 & 7 & 6 & 6 & 6 & 8 & 4 \\
\hline Receivables and payables ratio & 8 & 7 & 4 & 7 & 6 & 7 & 9 & 7 & 9 & 7 \\
\hline Equity to total assets & 3 & 1 & 3 & 2 & 1 & 2 & 4 & 2 & 4 & 1 \\
\hline Return on sales & 4 & 2 & 5 & 5 & 3 & 1 & 2 & 3 & 3 & 6 \\
\hline Return on investment & 7 & 8 & 10 & 9 & 10 & 9 & 8 & 9 & 7 & 10 \\
\hline Quick liquidity ratio & 1 & 3 & 1 & 3 & 2 & 4 & 1 & 1 & 1 & 3 \\
\hline Cash flow synchronicity ratio & 2 & 4 & 2 & 1 & 4 & 3 & 3 & 5 & 2 & 2 \\
\hline Plowback ratio & 10 & 9 & 8 & 10 & 9 & 10 & 7 & 10 & 5 & 9 \\
\hline Fixed asset renewal ratio & 5 & 6 & 7 & 4 & 8 & 5 & 5 & 4 & 6 & 5 \\
\hline
\end{tabular}

To assess opinion consistency, the authors have calculated Kendall's coefficient of concordance. Its value is 0.81 [(12 x 6,648): $(100 \times 990)]$, which testifies the high concordance of expert opinions and allows 
conducting importance ranking. The importance ranking within the strategic perspective "Financial" is given in "Table VI".

TABLE VI. THE IMPORTANCE RANKING OF INDICATORS WITHIN THE "FINANCIAL" STRATEGIC PERSPECTIVE

\begin{tabular}{|c|l|l|}
\hline Indicator & Weight & Rank \\
\hline Accounts receivable collection period & 0.058 & 9 \\
\hline Overdue receivables & 0.091 & 6 \\
\hline Receivables and payables ratio & 0.076 & 7 \\
\hline Equity to total assets & 0.142 & 2 \\
\hline Return on sales & 0.116 & 5 \\
\hline Return on investment & 0.062 & 8 \\
\hline Quick liquidity ratio & 0.136 & 3 \\
\hline Cash flow synchronicity ratio & 0.144 & 1 \\
\hline Plowback ratio & 0.056 & 10 \\
\hline Fixed asset renewal ratio & 0.120 & 4 \\
\hline
\end{tabular}

The results of the assessment of the "Internal

Business Processes" block are presented in "Table VII".

TABLE VII. THE RESUlts OF THE ASSESSMENT WITHIN THE STRATEGIC PERSPECTIVE "INTERNAL BUSINESS PROCESSES"

\begin{tabular}{|c|l|l|l|l|l|l|l|l|l|l|}
\hline Indicator & $\mathbf{E}_{\mathbf{1}}$ & $\mathbf{E}_{\mathbf{2}}$ & $\mathbf{E}_{\mathbf{3}}$ & $\mathbf{E}_{\mathbf{4}}$ & $\mathbf{E}_{\mathbf{5}}$ & $\mathbf{E}_{\mathbf{6}}$ & $\mathbf{E}_{\mathbf{7}}$ & $\mathbf{E}_{\mathbf{8}}$ & $\mathbf{E}_{\mathbf{9}}$ & $\mathbf{E}_{\mathbf{1 0}}$ \\
\hline Average duration of power outages in the system & 3 & 2 & 2 & 5 & 3 & 4 & 2 & 5 & 3 & 3 \\
\hline Total circuit losses & 1 & 3 & 4 & 2 & 1 & 2 & 1 & 3 & 1 & 2 \\
\hline Power recovery standard time & 4 & 5 & 1 & 6 & 2 & 1 & 4 & 1 & 2 & 1 \\
\hline Annual peak demand & 8 & 9 & 6 & 10 & 7 & 7 & 6 & 8 & 8 & 9 \\
\hline Use of electrical station installed capacity & 2 & 4 & 3 & 4 & 5 & 6 & 3 & 2 & 4 & 5 \\
\hline Average delay in reporting & 9 & 7 & 10 & 8 & 9 & 8 & 7 & 7 & 9 & 7 \\
\hline $\begin{array}{r}\text { Annual increased costs for improving electricity } \\
\text { grid quality }\end{array}$ & 10 & 8 & 9 & 1 & 10 & 9 & 8 & 9 & 10 & 10 \\
\hline Total active investments in the current quarter & 5 & 1 & 5 & 3 & 4 & 3 & 5 & 4 & 5 & 4 \\
\hline Instances of illegal consumption detected & 7 & 10 & 7 & 9 & 6 & 10 & 9 & 10 & 6 & 8 \\
\hline Equipment downtime & 6 & 6 & 8 & 7 & 8 & 5 & 10 & 6 & 7 & 6 \\
\hline
\end{tabular}

To assess opinion consistency, the authors have calculated Kendall's coefficient of concordance; its value is 0.73 [(12 x 6,054): $(100 \times 990)]$.

The importance ranking of the indicators within the "Internal Business Processes" strategic perspective is to be found in "Table VIII".
TABLE VIII. THE IMPORTANCE RANKING OF THE INDICATORS IN THE STRATEGIC PERSPECTIVE "INTERNAL BUSINESS PROCESSES"

\begin{tabular}{|c|l|l|}
\hline Indicator & Weight & Rank \\
\hline $\begin{array}{c}\text { Average duration of power } \\
\text { outages in the system }\end{array}$ & 0.151 & 3 \\
\hline Total circuit losses & 0.178 & 1 \\
\hline Power recovery standard time & 0.162 & 2 \\
\hline Annual peak demand & 0.049 & 7 \\
\hline $\begin{array}{c}\text { Use of electrical station } \\
\text { installed capacity }\end{array}$ & 0.138 & 4 \\
\hline Average delay in reporting & 0.042 & 8 \\
\hline $\begin{array}{c}\text { Annual increased costs for } \\
\text { improving electricity grid } \\
\text { quality }\end{array}$ & 0.036 & 10 \\
\hline $\begin{array}{c}\text { Total active investments in the } \\
\text { current quarter }\end{array}$ & 0.136 & 5 \\
\hline $\begin{array}{c}\text { Instances of illegal } \\
\text { consumption detected }\end{array}$ & 0.040 & 9 \\
\hline Equipment downtime & 0.069 & 6 \\
\hline \multicolumn{2}{|l|}{}
\end{tabular}

"Table IX" demonstrates the results of KPI ranking with a breakdown into strategic perspectives. 
TABLE IX. THE RESULTS OF KPI IMPORTANCE RANKING

\begin{tabular}{|c|c|c|c|c|}
\hline Rank & Financial & Customer & $\begin{array}{c}\text { Internal business } \\
\text { processes }\end{array}$ & $\begin{array}{l}\text { Personnel (Learning } \\
\text { and growth) }\end{array}$ \\
\hline 1 & $\begin{array}{l}\text { Cash flow } \\
\text { synchronicity ratio }\end{array}$ & Sales volume & Total circuit losses & $\begin{array}{l}\text { Number of suggested } \\
\text { improvements }\end{array}$ \\
\hline 2 & Equity to total assets & $\begin{array}{l}\text { Payment for the energy } \\
\text { supplied }\end{array}$ & $\begin{array}{ll}\text { Power } & \text { recovery } \\
\text { standard time } & \end{array}$ & Personnel turnover \\
\hline 3 & Quick liquidity ratio & Customer loyalty & $\begin{array}{l}\text { Average duration of } \\
\text { power outages in the } \\
\text { system }\end{array}$ & $\begin{array}{ll}\text { Personnel } & \text { satisfaction } \\
\text { index } & \end{array}$ \\
\hline 4 & $\begin{array}{l}\text { Fixed asset renewal } \\
\text { ratio }\end{array}$ & New customers & $\begin{array}{l}\text { Use of electrical station } \\
\text { installed capacity }\end{array}$ & Employee absenteeism \\
\hline 5 & Return on sales & $\begin{array}{l}\text { Share of high profile } \\
\text { customer dissatisfaction }\end{array}$ & $\begin{array}{l}\text { Total active investments } \\
\text { in the current quarter }\end{array}$ & $\begin{array}{l}\text { Share of payroll in the } \\
\text { revenue }\end{array}$ \\
\hline 6 & Overdue receivables & $\begin{array}{l}\text { Share of A-Customer } \\
\text { turnover }\end{array}$ & Equipment downtime & Average tuition fee \\
\hline 7 & $\begin{array}{l}\text { Receivables } \\
\text { payables ratio }\end{array}$ & $\begin{array}{l}\text { Complaints per } 1,000 \\
\text { customers }\end{array}$ & Annual peak demand & $\begin{array}{l}\text { Share of employees } \\
\text { with higher education }\end{array}$ \\
\hline 8 & Return on investment & $\begin{array}{l}\text { Average share of } \\
\text { customers with regular } \\
\text { power outages }\end{array}$ & $\begin{array}{l}\text { Average delay in } \\
\text { reporting }\end{array}$ & Training costs \\
\hline 9 & $\begin{array}{l}\text { Accounts receivable } \\
\text { collection period }\end{array}$ & $\begin{array}{l}\text { Share of sales outside } \\
\text { the traditional business } \\
\text { area }\end{array}$ & $\begin{array}{l}\text { Instances of illegal } \\
\text { consumption detected }\end{array}$ & $\begin{array}{l}\text { Share of managers with } \\
\text { management degrees }\end{array}$ \\
\hline 10 & Plowback ratio & $\begin{array}{l}\text { Claims won and settled } \\
\text { ratio }\end{array}$ & $\begin{array}{l}\text { Annual increased costs } \\
\text { for improving electricity } \\
\text { grid quality }\end{array}$ & $\begin{array}{l}\text { Average length of } \\
\text { employment in the } \\
\text { company }\end{array}$ \\
\hline
\end{tabular}

Each block requires optimal values of indicators. The optimal values for the "Financial" strategic perspective are shown in "Table X".

TABLE $X$. OPTIMAL VALUES OF INDICATORS IN THE "FINANCE" STRATEGIC PERSPECTIVE

\begin{tabular}{|c|l|l|}
\hline Indicator & $\begin{array}{c}\text { Actual } \\
\text { value for } \\
\mathbf{2 0 1 8}\end{array}$ & $\begin{array}{c}\text { Recommended } \\
\text { value }\end{array}$ \\
\hline $\begin{array}{c}\text { Cash flow } \\
\text { synchronicity ratio }\end{array}$ & 0.88 & 1.05 \\
\hline Equity to total assets & 0.46 & 0.50 \\
\hline Quick liquidity ratio & 0.72 & 1.00 \\
\hline $\begin{array}{c}\text { Fixed asset renewal } \\
\text { ratio }\end{array}$ & 0.15 & 0.21 \\
\hline Return on sales & 10.31 & 15.00 \\
\hline $\begin{array}{c}\text { Overdue receivables } \\
\text { Receivables and } \\
\text { payables ratio }\end{array}$ & 15.00 & 12.00 \\
\hline Return on investment & 0.68 & 0.90 \\
\hline $\begin{array}{c}\text { Accounts receivable } \\
\text { collection period }\end{array}$ & 54 & 16.00 \\
\hline Plowback ratio & 0.66 & 45 \\
\hline
\end{tabular}

The ranked data presented above can lay the foundation for the development of incentive systems.
IV. DEVELOPING THE BALANCED

SCORECARD TO ASSESS BUSINESS

PERFORMANCE UNDER THE EXISTING STRATEGY OF THE ORGANIZATION

The areas for the adaptation of a Balanced Scorecard in energy companies include:

- making management accounting more informative;

- creating business plans;

- providing linkages between strategic goals;

- identifying required performance indicators;

- checking performance indicators for compliance with strategic goals;

- performance indicators groups should correspond to the components of the Balanced Scorecard.

The development of a Balanced Scorecard should start with designing regulatory documentation on calculation and assessment of key performance indicators, granting of bonus payments and depriving of them.

The established Balanced Scorecard should include key performance indicators that reflect the performance 
of all units of company management. Some examples of such indicators include the following:

- quality of accounting and reporting;

- registration of ownership (performing all activities in the month under report, provided for in the roadmap/ action plan);
- compliance with deadlines for submission of data on overdue receivables;

- quality of claim review, etc.

The procedure for developing and establishing key performance indicators is given in "Table XI".

TABLE XI. DEVELOPMENT AND ESTABLISHMENT OF KEY PERFORMANCE INDICATORS

\begin{tabular}{|c|c|c|c|}
\hline Indicator & Calculation & Assessment method & Adjusting factor \\
\hline Collectability, \% & $\begin{array}{l}\text { The ratio of payment by } \\
\text { consumers to the cost of } \\
\text { the delivered services. }\end{array}$ & $\begin{array}{l}\text { The assessment is performed on a } \\
\text { monthly basis on a cumulative } \\
\text { total from the beginning of the } \\
\text { accounting year. The performance } \\
\text { of the indicator is estimated as a } \\
\text { ratio of the actual collectability to } \\
\text { the target value. The indicator } \\
\text { target is considered achieved if its } \\
\text { value is greater than or equal to } \\
100 \% \text {. }\end{array}$ & $\begin{array}{l}\text { The following adjusting } \\
\text { factors are applied to the } \\
\text { indicator: } \\
1.2 \text { if the completion rate is } \\
102 \% \text { or more; } \\
0.8 \text { if the completion rate is } \\
98 \%-99.9 \% \text {. }\end{array}$ \\
\hline $\begin{array}{l}\text { Achievement } r \\
\text { business plan targets } \\
\text { for accountable semi- } \\
\text { fixed costs, } \%\end{array}$ & $\begin{array}{l}\text { The ratio of actual } \\
\text { accountable costs to the } \\
\text { target value of } \\
\text { accountable costs. }\end{array}$ & $\begin{array}{l}\text { The assessment is performed on a } \\
\text { monthly basis on a cumulative } \\
\text { total from the beginning of the } \\
\text { accounting year. The indicator } \\
\text { target is considered achieved if its } \\
\text { value is less than or equal to } \\
100 \%\end{array}$ & $\begin{array}{l}\text { The following adjusting } \\
\text { factors are applied to the } \\
\text { indicator: } \\
0.5 \text { if the actual value is } \\
100.9 \%-105 \% \text { inclusive; } \\
1.2 \text { if its value is } 90 \% \text { or } \\
\text { less. }\end{array}$ \\
\hline $\begin{array}{lr}\text { Achievement } & \text { of } \\
\text { business plan targets } \\
\text { for Earnings Before } \\
\text { Interest, Taxes and } \\
\text { Amortization, } \%\end{array}$ & $\begin{array}{l}\text { The ratio of an actual } \\
\text { EBITDA to its target } \\
\text { value. }\end{array}$ & $\begin{array}{l}\text { The assessment is performed on a } \\
\text { monthly basis on a cumulative } \\
\text { total from the beginning of the } \\
\text { accounting year. The indicator } \\
\text { target is considered achieved if its } \\
\text { value is } 100 \%-109,9 \%\end{array}$ & $\begin{array}{l}\text { The following adjusting } \\
\text { factors are applied to the } \\
\text { indicator: } \\
0.5 \text { if its actual value is } 95 \% \\
-99.9 \% \text {; } \\
1.2 \text { if its actual value over } \\
\text { the reporting period is } 110 \% \\
\text { or more. }\end{array}$ \\
\hline
\end{tabular}

It is important to mention that the key performance indicators for the management can be both quantitative and qualitative.

\section{CONCLUSION}

To conclude, each strategic perspective is represented by key performance indicators. The article has outlined the recommended key performance indicators with a breakdown into four strategic perspectives: financial, customer, internal business process, and learning and growth. Each of the four strategic perspectives covers ten indicators.

The authors have applied the method of expert survey to rank indicators within each strategic perspective. Ten KPIs have been evaluated by experts, and Kendall concordance coefficients have been calculated to assess the consistency of expert opinions. This has allowed ranking the indicators according to their importance. Such ranking lay the foundation for the development of an incentive system. According to the experts, the most important indicators within strategic perspectives are:
- "Finance": Cash flow synchronicity ratio, Equity to total assets, Quick liquidity ratio;

- "Customer": Sales volume, Payment for the energy supplied, Customer loyalty (as a percentage);

- "Internal business processes": Total circuit losses (kWh), Power recovery standard time (hours), Average duration of power outages in the system (hours);

- "Personnel (Learning and growth)": Number of suggested improvements, Personnel turnover (as a percentage); Personnel satisfaction index.

The development of a Balanced Scorecard should start with designing regulatory documentation on calculation and assessment of key performance indicators, granting of bonus payments and depriving of them.

The established Balanced Scorecard should include key performance indicators that reflect the performance of all units of company management.

The development of standards for energy companies on calculation and assessment of key performance 
indicators is expected to simplify the introduction of a Balanced Scorecard into the accounting and management practices of energy companies in Russia.

\section{References}

[1] Balanced Scorecard. Translating strategy into action. 2nd ed. Moscow, Olymp-Business. 2014. 320 p.

[2] Tatenko G. I. Balanced scorecard and the management system of the organization. Economy and management in the conditions of the global competition: problems and prospects. Proceedings of the scientific and practical conference with the international participation. Ed. by A.V. Babkin. 2016. Pp. 404-411.

[3] Chelysheva E. A., Shulzhenko V. A. Balanced scorecard as an instrument for improving the system of financial planning at the enterprise. Zametki uchenogo. 2016. No. 8 (14). Pp. 61-67.

[4] Karimova A.M. Balanced scorecard in the system of management accounting. Actual directions of scientific researches in the field of Economics, Finance and accounting: from theory to practice. Proceedings of the VI All-Russian online conference. 2018. Pp. 115-120.

[5] Semanov A. A., Kurkina N. R. Implementation of enterprise management system on the basis of balanced scorecard. Forum of young scientists. 2018. No. 10 (26). Pp. 1076-1080.

[6] Kulagin V.N. Balanced scorecard to assess the functioning of the system of metrological support of the enterprise. Modern economy: topical issues, achievements and innovations. Proceedings of the XXVI International Scientific and Practical Conference. Penza, 2019. Pp. 12-16. 